Carneiro, J. et al. (2020)
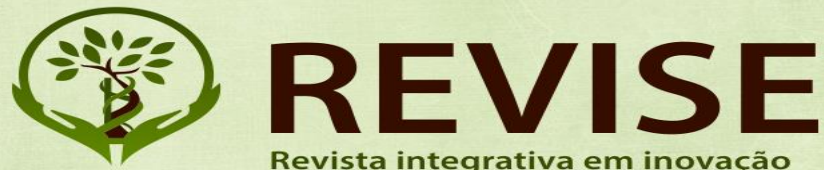

Revista integrativa em inovação tecnológica nas ciências da saúde

ISSN: $2179-6572$

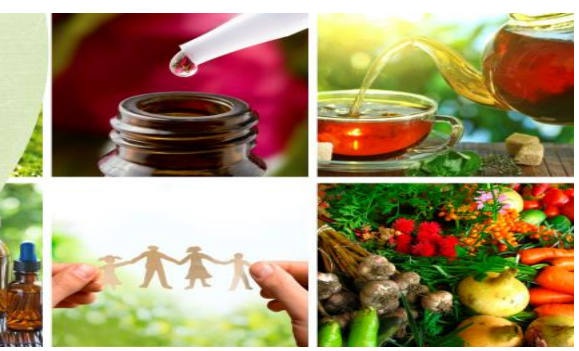

\title{
PRÁTICAS INTEGRATIVAS: DANÇAS CIRCULARES E EMOÇÕES DE DOUTORANDAS EM EDUCAÇÃO
}

\section{INTEGRATIVE PRACTICES: CIRCULAR DANCES AND EMOTIONS OF DOCTORAL STUDENTS IN EDUCATION}

\author{
Joanna Carneiro \\ Cristina D’Ávila \\ Camila Caribé \\ $U F B A$
}

\begin{abstract}
RESUMO
Fruto da síntese de uma tese de doutorado, este artigo revela uma pesquisa que tem como objetivo geral compreender como são vivenciadas as emoções de doutorandas em Educação, durante um período do doutoramento, expressas em relatos verbais e narrativas (auto)biográficas, a partir das danças circulares, tendo por base as teorias que tratam do saber sensível, raciovitalismo e da educação estética. Uma vez que é constatada a produção de sofrimento na formação de doutores ao longo do curso de pós-graduação, a relevância desta pesquisa reside, ainda, em disponibilizar às doutorandas em Educação um espaço ético e estético de formação, no contexto acadêmico, de escuta sensível, de acolhimento e de diálogo ante a necessidade de regulação entre razão e emoção, durante um período do doutorado. Conclui-se que as danças circulares, na pesquisa-formação desenvolvida, se constituem como Práticas Integrativas e Complementares e como dispositivo que promove emoções positivas/conjuntivas e possibilitam um diagnóstico de outras emoções, consideradas negativas/disjuntivas, capazes de provocar sofrimento psíquico, afetando a Saúde Mental de pósgraduandos e, consequentemente, sua vida acadêmica e social, podendo trazer repercussões negativas para a universidade. ${ }^{1}$
\end{abstract}

Palavras-chave: Danças Circulares. Emoções. Doutorandas. Educação.

\footnotetext{
${ }^{1}$ Não houve financiamento para a realização da pesquisa.
}

Danças Circulares. Revista Revise, v.05, fluxo contínuo (2020): Dossiê experiências de integração ensino-serviço nas Práticas Integrativas e Complementares, p. 37-60. 


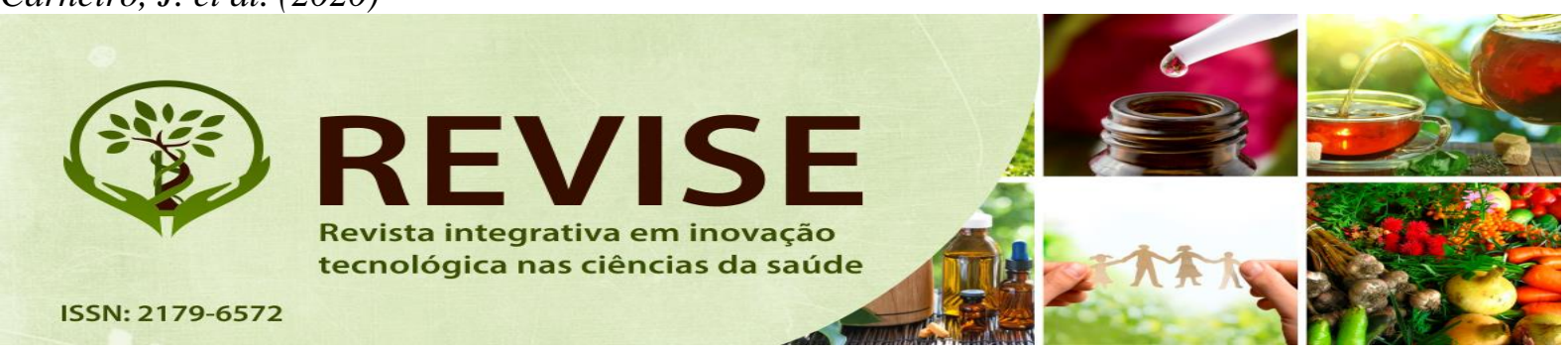

\begin{abstract}
Resulting from the synthesis of a doctoral thesis, this article reveals a research that has as its general objective to understand how the emotions of doctoral students in Education are experienced, during a period of the doctorate, expressed in verbal reports and (self)biographical narratives, from the circular dances, based on theories that deal with sensitive knowledge, raciovitalism and aesthetic education. Once the production of suffering is verified in the training of doctors throughout the postgraduate course, the relevance of this research also lies in making available to the PhD students in Education an ethical and aesthetic space of training, in the academic context, of sensitive listening, welcoming and dialogue in the face of the need for regulation between reason and emotion, during a $\mathrm{PhD}$ period. It is concluded that the circular dances, in the research-training developed, are constituted as Integrative and Complementary Practices and as a device that promotes positive/conjunctive emotions and allows a diagnosis of other emotions, considered negative/disjunctive, capable of causing psychic suffering, affecting the Mental Health of postgraduate students and, consequently, their academic and social life, which can bring negative repercussions for the university.
\end{abstract}

Keywords: Circular Dances. Emotions. Doctoral students. Education.

\title{
INTRODUÇÃO
}

O tema do presente artigo, fruto da síntese de uma tese de doutorado, refere-se à formação de doutorandas em Educação, em uma perspectiva sensível. A pesquisa foi estruturada com o objetivo geral de compreender como são vivenciadas as emoções de doutorandas em Educação, durante um período do doutoramento, expressas em relatos verbais e narrativas (auto)biográficas, a partir das danças circulares. Os objetivos específicos foram: 1) Escutar as emoções vivenciadas pelas doutorandas em Educação, durante um período do doutoramento, expressas em relatos verbais a partir das danças circulares; 2) Descrever as emoções vivenciadas pelas doutorandas em Educação, durante um período do doutoramento, expressas em narrativas (auto)biográficas a partir das danças circulares; 3) Identificar categorias referentes às emoções vivenciadas pelas doutorandas em Educação durante um período do doutoramento, expressas em relatos verbais e narrativas (auto)biográficas a partir das danças circulares.

Danças Circulares. Revista Revise, v.05, fluxo contínuo (2020): Dossiê experiências de integração ensino-serviço nas Práticas Integrativas e Complementares, p. 37-60. 


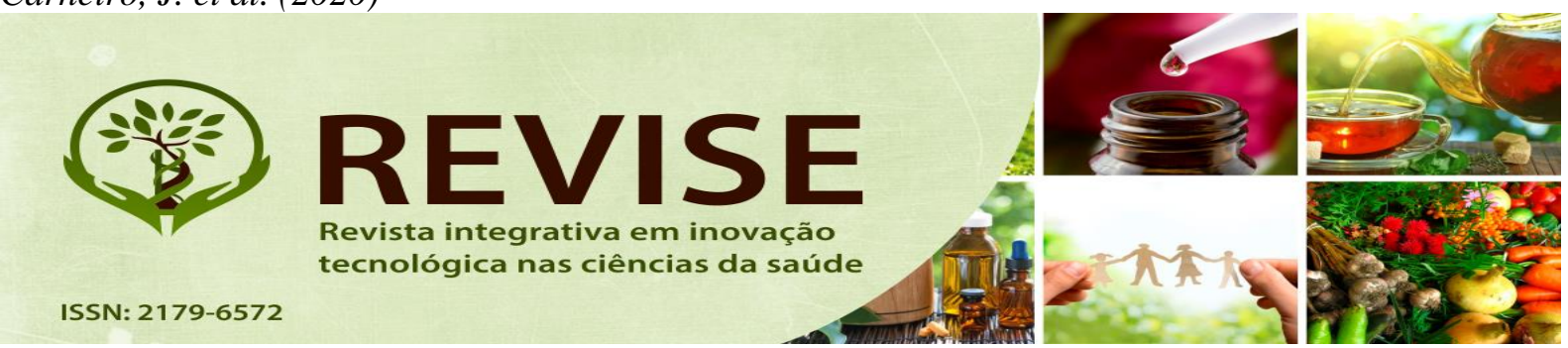

Parte-se, por um lado, do pressuposto de que a experiência de realização de um curso de pósgraduação eleva a autoestima e está recheada de emoções positivas/conjuntivas no processo formativo, despertando a curiosidade, criatividade e vontade de aprender, ao mesmo tempo em que exige persistência, dedicação e disciplina. Por outro lado, tal experiência formativa é vivida, também, com emoções consideradas negativas/disjuntivas relativas a episódios depressivos, medo, insegurança, ansiedade, tensões, conflitos, angústias e resistências. Tal constatação reforça o dito por Maturana (1998) que o viver humano ocorre em um contínuo entrelaçamento de emoções gerando tensões.

Dessa forma, a relevância desta pesquisa reside, ainda, em disponibilizar às doutorandas em Educação um espaço ético e estético de formação, no contexto acadêmico, segundo o que estabelecem as Resoluções 466 e 510 (BRASIL, 2012, 2016) de escuta sensível (BARBIER, 2002), de acolhimento, de diálogo ante a necessidade de regulação entre razão e emoção, durante um período do doutorado, uma vez que é constatada a produção de sofrimento na formação de doutores ao longo do curso de pós-graduação.

Este artigo está estruturado em seis seções, incluindo esta Introdução, a qual traz o objetivo geral, os objetivos específicos, a problemática e a relevância científica, além de apresentar uma visão panorâmica preliminar da estrutura do trabalho desenvolvido.

Na segunda seção, Emoções na pós-graduação, o conceito de emoções é anunciado, a classificação das emoções positivas/conjuntivas e negativas/disjuntivas (ADLER, 1957) é apresentada, além de discorrer sobre algumas pesquisas, no âmbito dos programas brasileiros de pósgraduação, referentes às emoções negativas/disjuntivas que envolvem quadros clínicos desde ansiedade, depressão, pânico, paranoia, até desfechos de suicídios, relatadas pelos pós-graduandos ou através de porta-vozes dos programas, denunciando, portanto, uma polaridade sintomática, enfrentada com intenso mal-estar e angústia durante o processo formativo.

A terceira seção, Da importância de uma formação sensível, trata do cuidado com as emoções na formação de pós-graduandos em uma perspectiva sensível, trazendo referências teóricas sobre o saber sensível e raciovitalismo (MACEDO, 2010; ARAÚJO, 2006, 2018; MAFFESOLI, 1998; DUARTE-JÚNIOR, 2012), além de apresentar os dispositivos dos Ateliês Biográficos de integração ensino-serviço nas Práticas Integrativas e Complementares, p. 37-60. 


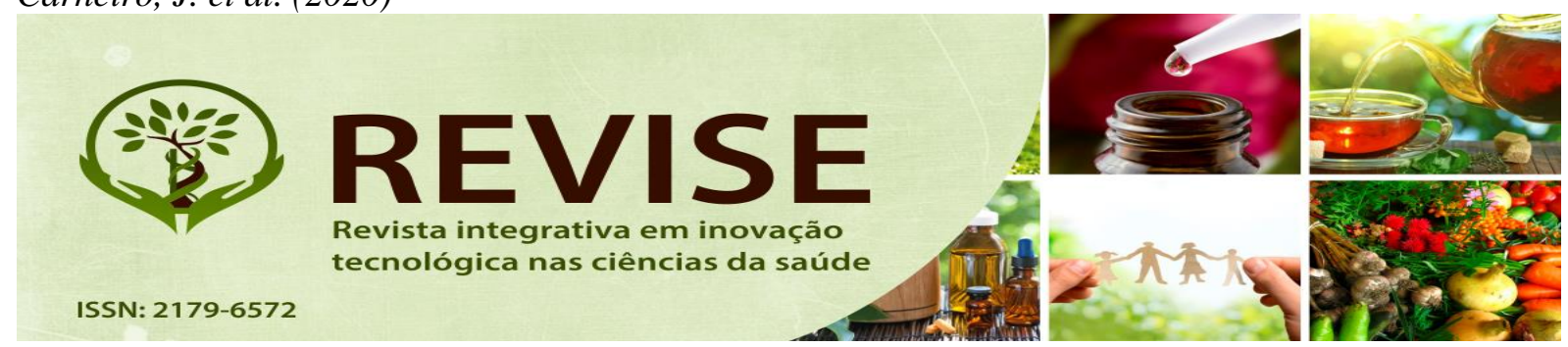

Projeto (DELORY-MOMBERGER, 2006) e das Danças Circulares (BRASIL, 2017; OSTETTO; KOLB-BERNARDES, 2015; CARVALHO, 2017; WOSIEN, 2000) e, especificamente, o dispositivo das Danças Circulares dos florais de Bach (GENG, 2016; BARRETO, 2014, 2018; SCHEFFER, 1984; BACH, 1990).

A Metodologia é focada na seção de número quatro, subdividida da seguinte forma: a) Delineamento; b) Contexto e seleção de participantes; c) Descrição das participantes; d) Vivências com 6 danças circulares dos Florais de Bach; e) Instrumentos para produção de dados; f) Organização e análise dos dados e g) Princípios éticos.

A seção de número cinco, intitulada Resultados e Discussão, apresenta os registros das emoções expressas que mais se repetiram tanto nos relatos verbais quanto nas narrativas (auto)biográficas das doutorandas em Educação, a partir das danças circulares dos florais de Bach, além disso, verificou-se no grupo pesquisado a presença das 4 emoções universais e seus equivalentes semânticos (DARWIN, 2009; EKMAN, 2011; ADLER, 1957; ACCIOLY; ATHAYDE, 1996). Desse modo, segue-se a análise interpretativas no nível grupal, lançando-se mão das contribuições teóricas dos autores que estudam as temáticas das danças circulares, das emoções e da formação em uma perspectiva sensível.

Na sexta e última seção, denominada Conclusão, são apontados os elementos que contribuem para a compreensão da necessidade de investigação do objeto de estudo, ou seja, a compreensão das emoções de doutorandas em Educação, na perspectiva do cuidado com a Saúde Mental, apresentandose outras questões que podem ser retomadas em investigações futuras. Por fim, as contribuições do estudo para o meio acadêmico são esboçadas, sobretudo, para a pós-graduação.

Sendo assim, este artigo tem como objetivo contribuir para o debate sobre o cuidado com as emoções nos campos do ensino e pesquisa na pós-graduação no Brasil.

\section{EMOÇÕES NA PÓS-GRADUAÇÃO}

O primeiro cientista a reconhecer as manifestações de emoções no corpo como formas de comunicação não verbal e expressão de sentimentos foi Darwin (2009), em seu livro A expressão das

Danças Circulares. Revista Revise, v.05, fluxo contínuo (2020): Dossiê experiências de integração ensino-serviço nas Práticas Integrativas e Complementares, p. 37-60. 


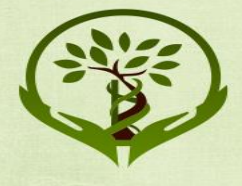

ISSN: $2179-6572$
REVISE

Revista integrativa em inovação tecnológica nas ciências da saúde
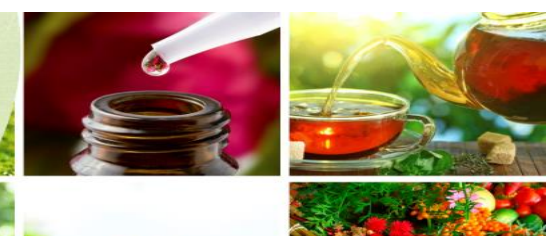

emoções no homem e nos animais. Desde o final do século XIX, ele demonstrou, por meio de pesquisas, a expressão das emoções, tanto no homem quanto nos animais, evidenciando a universalidade das expressões emocionais, com a coleta de dados, a partir de colaboradores em várias partes dos continentes, tendo assim material suficiente para sustentar as conclusões que apresenta em sua obra.

De acordo com o autor referido:

Os movimentos expressivos do rosto e do corpo, qualquer que seja sua origem, são por si mesmos muito importantes para o nosso bem-estar. Eles são o primeiro meio de comunicação entre a mãe e seu bebê; sorrindo, ela encoraja seu filho quando está no bom caminho; senão, ela franze o semblante em sinal de desaprovação (DARWIN, 2009, p. 310).

Em outra passagem do livro, Darwin (2009) aponta, desde então, um conhecimento acerca das emoções que seriam denominadas universais (EKMAN, 2011) e que se manifestam nas expressões faciais dos humanos e dos animais, tais como tristeza, medo, raiva e alegria.

Ekman (2011, p. 16) define emoções universais como emoções que “[...] possuem expressões evidentemente comuns". Ele introduz o termo emoções universais para definir as emoções, denominadas por outros autores, como básicas, simples, perceptuais, iniciais, primárias, inatas, préorganizadas (ACCIOLY; ATHAYDE, 1996; HARRIS, 1996; LOWEN, 1979, 1982; DAMÁSIO, 1996). Ele considerou sete emoções universais e seus equivalentes semânticos, ou seja, famílias afins das emoções. As sete emoções universais elencadas por Ekman (2011) dizem respeito a: tristeza, raiva, surpresa, medo, aversão, desprezo e felicidade.

Para efeito da pesquisa realizada, foram consideradas as emoções universais, básicas, primárias, simples, perceptuais, iniciais, inatas, pré-organizadas correspondentes ao medo, à raiva, à tristeza e à alegria, definidas, ainda nesta seção, uma vez que os estudos citados no corpo do presente trabalho apontam que tais emoções têm expressões evidentemente comuns (EKMAN, 2011) e podem ser mais facilmente observadas por expressões faciais.

A emoção é um fenômeno complexo, que envolve aspectos psíquicos e corporais. Essa complexidade produz dificuldades em seu estudo, relacionadas tanto ao consenso de sua própria

Danças Circulares. Revista Revise, v.05, fluxo contínuo (2020): Dossiê experiências de integração ensino-serviço nas Práticas Integrativas e Complementares, p. 37-60. 


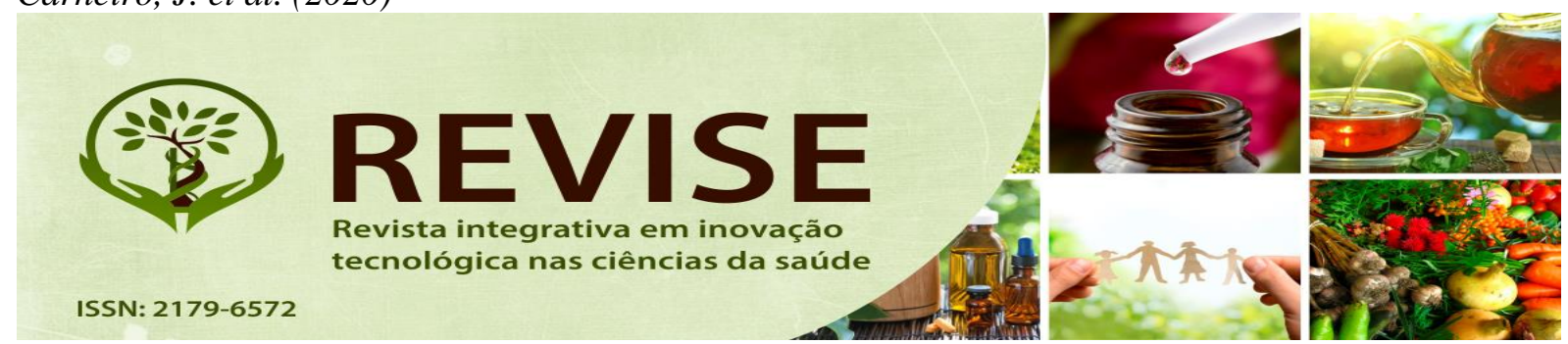

definição, quanto ao compartilhamento do seu significado. No senso comum, diversos termos são utilizados para definir uma emoção, o principal deles é o sentimento, aplicado muitas vezes referindose às emoções. Essas últimas, segundo Dalgalarrondo (2000), diferem dos sentimentos por serem menos estáveis e de curta duração. Damásio (2004, p. 19) distingue os dois termos, afirmando que "[...] as emoções desenvolvem-se no teatro do corpo, enquanto que os sentimentos surgem no teatro da mente".

A palavra emoção deriva de e-movere, que significa "mover para fora" ou "sair de si", ou seja, quando um indivíduo se emociona, transmite para o exterior algo que indica uma manifestação corporal, o que pode ocorrer por meio da voz, do corpo, onde se incluem as expressões faciais ou movimentos de outra ordem (BESCHE-RICHARD; BUNGENER, 2008).

De acordo com Dalgalarrondo (2000, p. 20), as emoções podem ser definidas como reações afetivas agudas, carregadas de vitalidade, momentâneas, desencadeadas por estímulos significativos. Assim, a emoção é um “[...] estado afetivo intenso, de curta duração, originado geralmente como uma reação do indivíduo a certas excitações internas ou externas, conscientes ou inconscientes".

Harris (1996) classifica as emoções entre simples e complexas pela facilidade de reconhecer uma expressão facial. Dessa forma, as emoções de raiva, medo, tristeza e alegria teriam expressões faciais mais facilmente reconhecíveis, sendo consideradas emoções simples. Por outro lado, as emoções complexas não teriam uma figura facial ou expressões comportamentais tão óbvias. A vergonha, o orgulho e a culpa exemplificam esse grupo. Para o referido autor, tanto emoções simples como emoções complexas podem ser positivas, negativas ou mistas. As emoções positivas seriam oriundas de situações agradáveis; as negativas oriundas de situações desagradáveis. Esta diversidade de emoções que abrange sentimentos de ambivalência relacionados a uma única situação é chamada de emoções mistas (HARRIS, 1996).

O caráter de um ser humano, de acordo com a tese fundamental de Adler (1957), nunca deve servir para base de um julgamento moral, e sim, como índice da sua atitude para com seu ambiente e de suas relações com a sociedade em que vive. Na elaboração da sua tese, o autor menciona dois fatos humanos universais: 1) a existência universal de um sentimento de sociabilidade que liga os homens entre si, que se manifesta via solidariedade com os outros, tornando a existência frutífera e valiosa.

Danças Circulares. Revista Revise, v.05, fluxo contínuo (2020): Dossiê experiências de integração ensino-serviço nas Práticas Integrativas e Complementares, p. 37-60. 


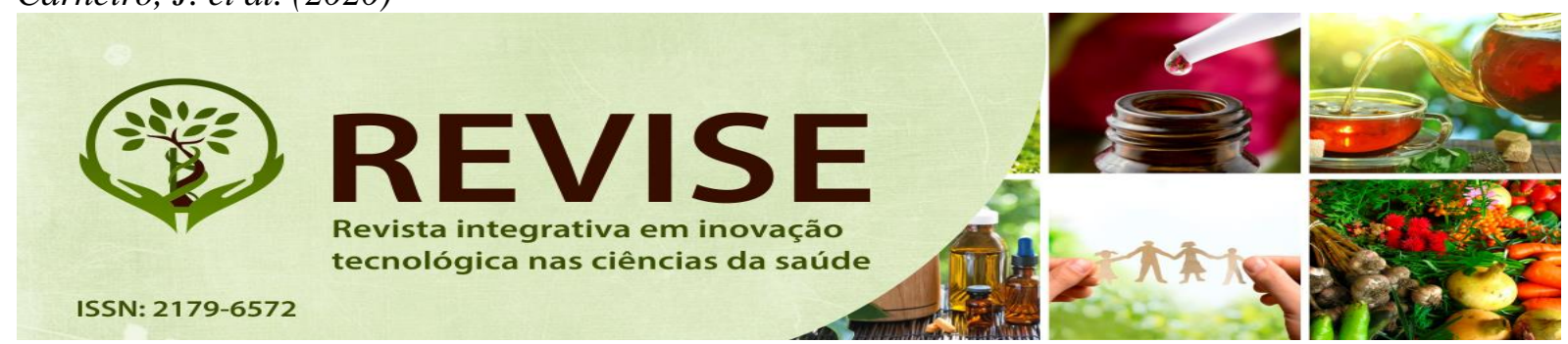

De acordo com Adler, temos aí o embrião das emoções positivas/conjuntivas referentes à alegria, simpatia e modéstia; 2) as energias hostis ligadas ao sentimento social, as quais são as tendências e esforços para conseguir poder pessoal e superioridade. Decorrem, portanto, a partir desse princípio, as emoções negativas/disjuntivas relacionadas à cólera, tristeza, repugnância, medo e ansiedade. Estes dois fatos, segundo o autor, estão sempre em conflito um com o outro, atuando como uma conjugação dinâmica de forças, fatos estes aqui relatados e observados durante o desenvolvimento da pesquisa.

Accioly e Athayde (1996, p. 22) apresentam o seguinte conceito de emoção: “[...] reação organísmica total, coordenada pelo cérebro ante estímulos externos e/ou internos, promovendo condutas adequadas para preservação da vida, ante ameaças e para sua manutenção e da espécie”. O conceito referido, segundo os autores, estabelece a emoção como uma reação vital dos seres vivos, com o objetivo fundamental da manutenção da vida. Exclui-se, desse modo, a influência da alma como agente sobrenatural determinante ou como sede das emoções.

A seguir, a definição das categorias utilizadas na pesquisa desenvolvida, correspondentes a quatro das emoções consideradas universais, referentes ao medo, à raiva, à tristeza e à alegria, descritas por Ekman (2011), Accioly e Athayde (1996), Lowen (1979, 1997), Lessa (2014), Mira y López (1992) e Descartes (2012) é apresentada:

- Medo: emoção que induz um movimento de fuga, constituindo um complexo dispositivo defensivo, podendo conduzir à regressão. Essa emoção é importante e necessária para fugir do perigo, preservando a vida do ser. Existe uma variedade de denominações que correspondem às condutas do medo, tais como: timidez, indecisão, confusão, ansiedade, angústia, fobia, temor, preocupação, vergonha, culpa, entre outras.

- Raiva: emoção que invoca uma resposta de ataque e defesa. Diante de um estímulo externo que ameaça a vida ou a integridade física, torna-se necessária a raiva para defesa da vida. Comumente, usam-se, para a emoção da raiva, denominações linguísticas, tais como: ressentimento, vingança, irritação, chateação, frustração, decepção, mágoa, ciúme, inveja, desagrado, falso triunfo, entre outras.

Danças Circulares. Revista Revise, v.05, fluxo contínuo (2020): Dossiê experiências de integração ensino-serviço nas Práticas Integrativas e Complementares, p. 37-60. 


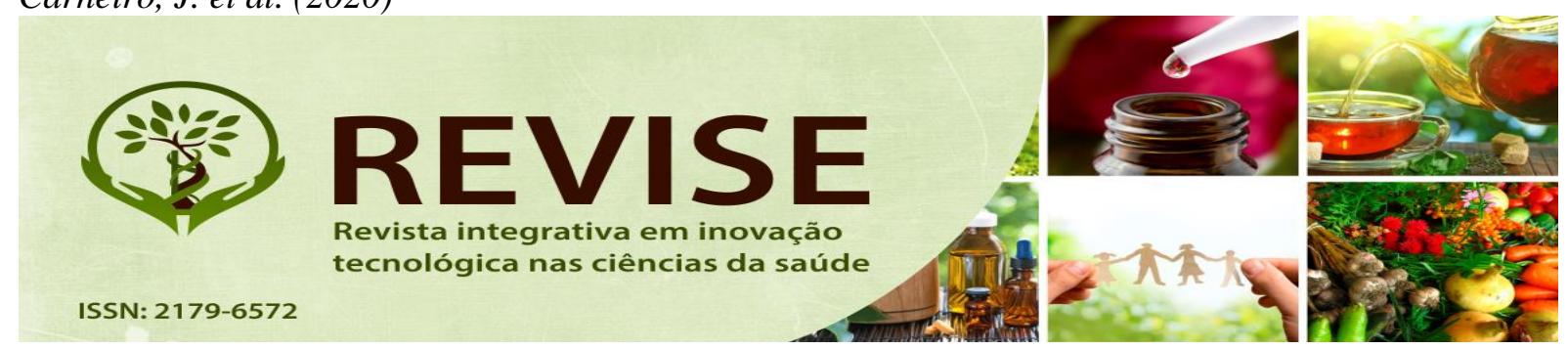

- Tristeza: diferente das demais emoções, a tristeza não induz movimento, ao contrário, ela leva à paralisação e ao isolamento. Trata-se de um langor desagradável e pode ser desencadeada por um estímulo externo, em situações de perdas materiais e pessoais, por morte ou separação. A perda pode ser de pessoas ou objetos de grande significação. Como as emoções já descritas, a tristeza é desencadeada por estímulos internos e, em decorrência do desconhecimento do tema e denominações linguísticas que a escondem, as pessoas apresentam condutas decorrentes dessa emoção e dizem que são ou estão: desiludidas, com solidão, com nostalgia, desprezadas, desgostosas, rejeitadas, desesperadas, amarguradas, deprimidas, desanimadas, entre outras expressões.

- Alegria: induz um movimento de aproximação, sendo uma agradável emoção, na qual reside o prazer. Trata-se de uma emoção vitalizante, que conduz o ser humano a uma existência plena. Usualmente relacionada à composição com outro corpo, consequenciando potência e emoção. De maneira geral, a alegria está interrelacionada ao amor, que corresponde a uma ligação vital com uma fonte de vida alegre, quer essa fonte seja um indivíduo, uma comunidade, a natureza ou o universo. Na alegria, existem construções referentes a equivalentes semânticos tais como: amor, ânimo, bem-estar, confiança, equilíbrio, força, gratidão, leveza, libertação, paz, resiliência/superação e tranquilidade.

Em continuação, são apresentados estudos e pesquisas (MORAES, 2017), que tem revelado dados de transtornos psíquicos leves, moderados ou graves, desde quadros clínicos de desgaste emocional, abrangendo ansiedade, depressão, fobia, pânico, até desfechos de suicídios em mestrandos e doutorandos de diversas áreas de conhecimento.

As narrativas, extraídas do jornal Folha de São Paulo (MORAES, 2017), relatam o estado mental dos alunos de mestrado e doutorado, em sofrimento psíquico, intensos sintomas, a relação difícil e persecutória com o (a) orientador (a), a rejeição à dissertação e/ou tese, o sentimento de humilhação social, a escassez dos recursos materiais e financeiros durante a pós-graduação, conforme depoimentos a seguir indicados:

Danças Circulares. Revista Revise, v.05, fluxo contínuo (2020): Dossiê experiências de integração ensino-serviço nas Práticas Integrativas e Complementares, p. 37-60. 


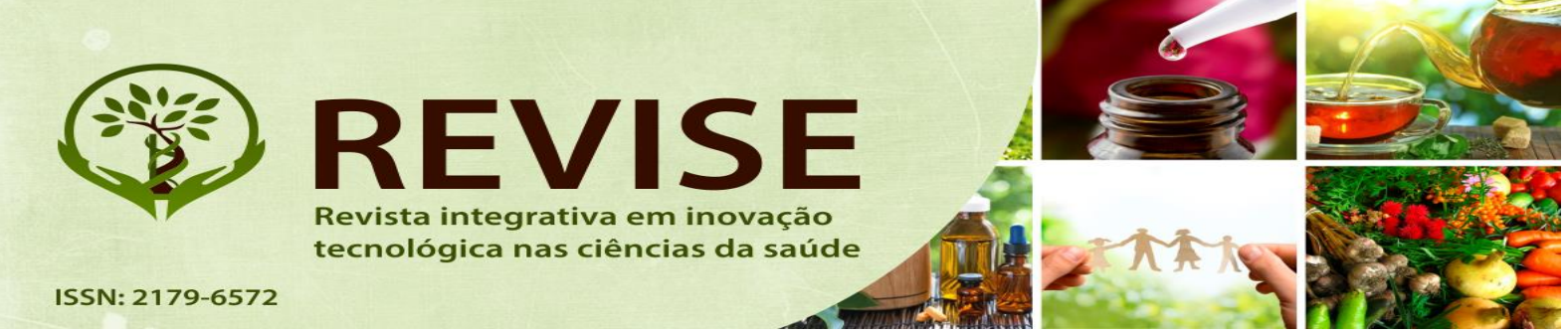

- Ele estava travado. 'O doutorado dele parecia que não ia', disse um amigo que pediu à reportagem que não o identificasse.

- Não se trata de transformar a figura do orientador num terapeuta, mas me parece fundamental que ele tenha sensibilidade às características de cada aluno.

- Minha orientadora sumia por meses. Faltando algumas semanas para a defesa, ela viajou para o exterior. Escrevi tudo sozinha, sem direcionamento, até a sua volta, quando precisei virar noites para terminar a tempo. Acordei diversas vezes sem querer acordar. Levantar da cama e encarar o dia era um desafio que eu não conseguia enfrentar sem derramar lágrimas.

- $\quad$ Fiz terapia durante quase todo o processo, mas precisei parar no final, pois a minha bolsa terminou; o programa de pós nunca ofereceu auxílio psicológico.

- Cinco anos depois da defesa, a minha tese continua jogada na estante e não consigo sequer olhar para ela. Entrei no doutorado, mas acabei desistindo. Hoje estou bem com essa escolha, pois o meio acadêmico não é para pessoas sensíveis.

Malagris e colaboradores (2009) investigaram a presença e o nível de estresse em 140 alunos de pós-graduação de todos os centros universitários na Universidade Federal do Rio de Janeiro (UFRJ), usando o Inventário de sintomas de estresse para adultos, padronizado por Lipp e Guevara (1994), identificando algumas características sociobiográficas. A faixa etária dos participantes foi entre 23-38 anos, sendo 74 mulheres e 66 homens. Verificou-se que 58,6\% dos alunos estavam estressados. O índice de estresse mais elevado foi encontrado no Centro de Ciências da Matemática e da Natureza (82,4\%), seguindo-se do Centro Tecnológico (61\%), Fórum de Ciência e Cultura (60\%), Centro de Letras e Artes e Centro de Filosofa e Ciências Humanas (55\%), Centro de Ciências Jurídicas e Econômicas e Centro de Ciências da Saúde (50\%). O índice de estresse encontrado é bastante preocupante, podendo relacionar-se a demandas específicas de cursos de mestrado ou doutorado. Os autores apontam a importância de desenvolver estudos que identifiquem os estressores específicos.

Na Universidade Federal do Rio Grande do Sul (UFRGS), uma pesquisa foi conduzida pela Associação de Pós-Graduandos, por Blanco e Araújo (2013 apud JUNTA, 2017), através de um

Danças Circulares. Revista Revise, v.05, fluxo contínuo (2020): Dossiê experiências de integração ensino-serviço nas Práticas Integrativas e Complementares, p. 37-60. 


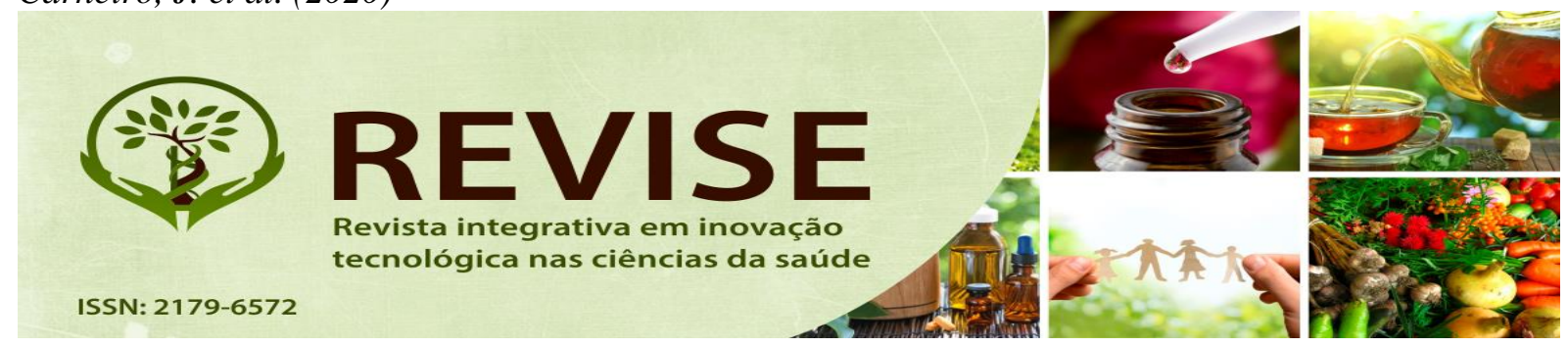

questionário socioeconômico, investigando os índices de depressão entre pós-graduandos, com uma questão relativa à Saúde Mental nos cursos de especialização, mestrado e doutorado na Universidade: "Você já sentiu ou sente dificuldades de interação social, mudanças no apetite, aumento da irritabilidade, não habilidade para assistir aulas e/ou fazer pesquisas, dificuldade de concentração e problemas no sono, insônia ou sono não restaurador em algum momento após ter entrado em um curso de pós-graduação?”.

Os resultados do estudo apontaram índices elevados para os mestrandos e doutorandos na situação de enfrentamento dos sintomas, quando comparados aos estudantes de especialização. Em todas as alternativas, mestrandos e doutorandos apresentaram uma frequência maior de problemas. Os mestrandos e doutorandos da UFRGS, em 2013, estavam aproximadamente 3 vezes menos sociáveis, 2 vezes mais irritados, 1 vez e meia com mais dificuldades de apetite e menos motivados, e quase 1 vez e meia com mais problemas para dormir do que os estudantes dos cursos de especialização.

Junta (2017) sinaliza, ainda, que não se trata de uma particularidade da UFRGS e cita outro estudo, realizado em 2005, com estudantes de pós-graduação do curso de Medicina Veterinária da Universidade Estadual Paulista (UNESP), que destaca o surgimento de distúrbios físicos e/ou psicológicos, sobretudo o fenômeno do estresse. Os sintomas mais referidos pelos alunos de pósgraduação foram ansiedade (89\%), irritabilidade (77\%), angústia (64\%), desânimo (63\%) e dificuldade de concentração $(61 \%)$.

Iniciativas têm sido verificadas referentes à criação de serviços de atenção ao estudante de graduação e pós-graduação. Tem-se como exemplo o Serviço de Atenção ao Estudante de Letras (SAEL), na Universidade Federal de Minas Gerais (UFMG), como uma resposta à demanda surgida durante a Semana de Saúde Mental, realizada no primeiro semestre do ano de 2017 pelo Diretório Acadêmico da Faculdade de Letras. O atendimento é prestado por assistentes sociais e psicólogos.

As pesquisas acessadas até o presente momento, sobre o assunto, indicam altos índices de depressão e de outras emoções negativas/disjuntivas na pós-graduação e a problemática se torna mais grave com a insistência da academia em não enfrentá-la (JUNTA, 2017; BÉRGAMO; MORAES, 2017).

Danças Circulares. Revista Revise, v.05, fluxo contínuo (2020): Dossiê experiências de integração ensino-serviço nas Práticas Integrativas e Complementares, p. 37-60. 


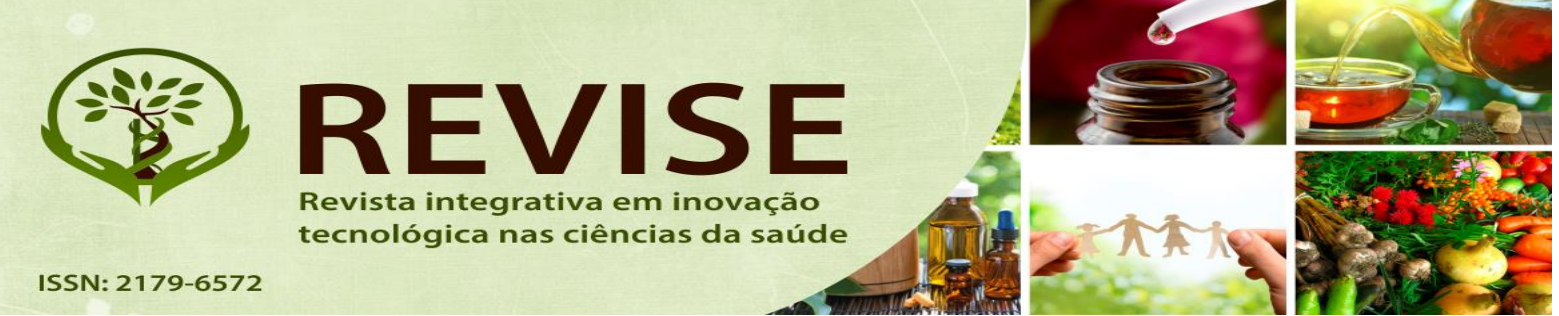

\section{DA IMPORTÂNCIA DE UMA FORMAÇÃO SENSÍVEL}

Para Macedo (2010), formar-se constitui uma aprendizagem significativa em níveis também da sensibilidade. O cenário formativo inclui a autoformação, heteroformação e transformação, implicando uma formação da sensibilidade, caracterizada pela nossa capacidade de lidar com os afetos investidos nas nossas experiências relacionais, muitas vezes opacas, não compreendidas, mas ativas e instituintes, segundo o autor referido.

De acordo com Araújo (2006), o cuidado com o sensível nos conduz à compreensão viva da complexidade do humano. Instiga-nos a aprender, mediante a formação de vínculos intensivos consigo próprio e com os outros, estimulando a simpatia, a postura de coparticipação e a não indiferença.

Maffesoli (1998) nos fala de uma lógica, desprezada pelos racionalistas ocidentais, integrando razão e sensibilidade, que exprime a sinergia da razão e do sensível. Nesta lógica, portanto, o afeto, o emocional, o afetual, coisas que são da ordem da paixão, não estão mais separadas em um domínio à parte, e sim, integradas. Dessa forma, o conceito de raciovitalismo gravita por Maffesoli (1998, p. 113), na ideia de que "[...] é possível realizar uma nova harmonia que encontra seu fundamento na vida e para além das diversas fragmentações, na potência do todo".

Temos, então, para a formação, um saber específico referente ao saber sensível, traduzido como:

[...] a nossa capacidade de sentir, de nos movermos fisicamente, de perceber o mundo através dos sons, das cores, odores, texturas e sabores. Este saber difere, portanto, do conhecimento inteligível, denominado como produto de nossa inteligência simbólica (DUARTE-JÚNIOR, 2012, p.1).

Inserida na dimensão sensível em que a pesquisa se norteou, estabeleceu-se como dispositivos de acolhimento, de sensibilização e de produção de dados, os Ateliês Biográficos de Projeto (DELORY-MOMBERGER, 2006) e as danças circulares, recentemente reconhecidas como Práticas Integrativas e Complementares, segundo a Portaria nº 849, de 27 de março de 2017 (BRASIL, 2017).

Danças Circulares. Revista Revise, v.05, fluxo contínuo (2020): Dossiê experiências de integração ensino-serviço nas Práticas Integrativas e Complementares, p. 37-60. 


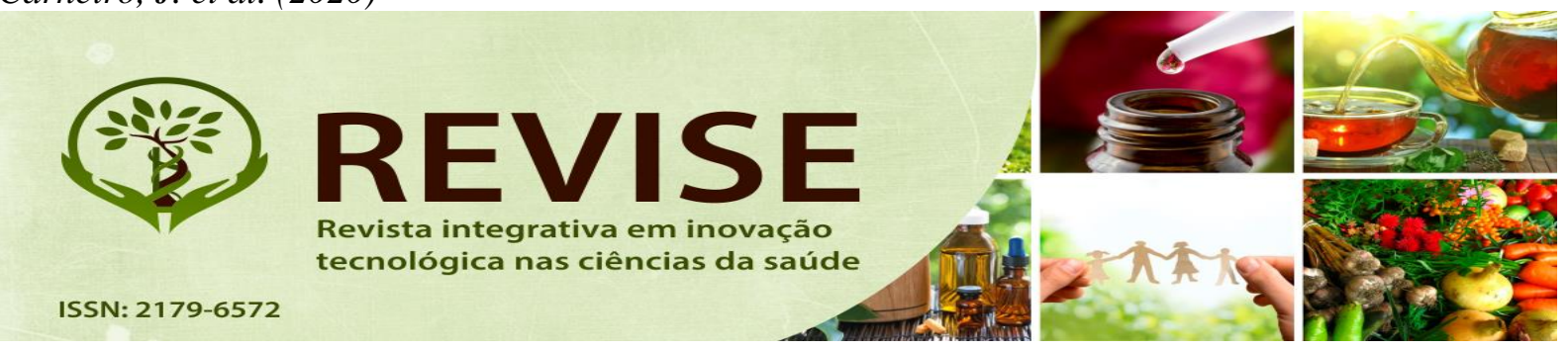

As danças circulares são práticas de danças em roda, tradicional e contemporânea, originárias de diferentes culturas que favorecem a aprendizagem e a interconexão harmoniosa entre os participantes. Os indivíduos dançam juntos, em círculos e, aos poucos, começam a internalizar os movimentos, liberar a mente, o coração, o corpo e o espírito; neste espaço, sentem-se acolhidos e alvo de cuidado integral, fator que favorece o processo de autorregulação emocional. Por meio do ritmo, da melodia e dos movimentos delicados e profundos, os integrantes da roda são estimulados a respeitar, aceitar e honrar as diversidades.

As danças circulares podem criar espaços significativos para o desenvolvimento de estados emocionais positivos/conjuntivos, tornando-se um recurso importante no contexto de grupos, uma vez que estimulam a cooperação, despertam o respeito ao outro, a sociabilidade, a integração, a inclusão e o acolhimento às diversidades. A prática tem o potencial mobilizador da expressão de afetos e de reflexões que resultam na ampliação da consciência das pessoas.

Ostetto e Kolb-Bernardes (2015), em uma pesquisa desenvolvida, realizaram um trabalho biográfico com um grupo de jovens do mestrado em Pedagogia do Teatro da Universidade de Rostock (norte da Alemanha), público-alvo que se aproximou ao da investigação aqui relatada. Inspirado na proposta de "Ateliê Biográfico de Projeto", o trabalho procurou amplificar possibilidades nos modos de falar de si, utilizando-se de diferentes linguagens e materialidades expressivas, incluindo as danças circulares. Pressupondo a dimensão estética, poética, dos processos de produção de narrativas autobiográficas, o convite à imaginação criadora mobilizou, no campo da sensibilidade, a compreensão e a escrita de si nos participantes.

Segundo Carvalho (2017), a maioria das danças encontradas por Wosien (2000) foi de natureza alegre e vibrante. Tais danças foram denominadas Solares. No entanto, ele coreografou também danças introspectivas, chamadas Lunares. Com a evolução natural dos anos, outras danças foram surgindo e sendo consideradas sagradas: danças da gestualidade, de oração e as danças dos florais de Bach. A seguir, serão tecidas algumas considerações e informações a respeito das danças circulares dos florais de Bach, dispositivo específico utilizado na pesquisa.

De acordo com Geng (2016) e Barreto (2014, 2018), as danças circulares dos florais de Bach se inspiraram na sabedoria da natureza para buscar a saúde e compartilhar o cuidado nas relações com

Danças Circulares. Revista Revise, v.05, fluxo contínuo (2020): Dossiê experiências de integração ensino-serviço nas Práticas Integrativas e Complementares, p. 37-60. 


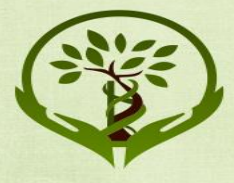

ISSN: 2179-6572

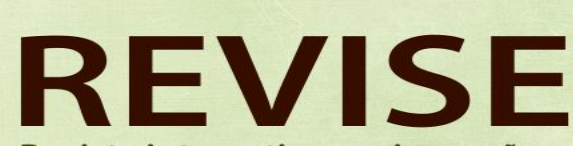

Revista integrativa em inovação tecnológica nas ciências da saúde
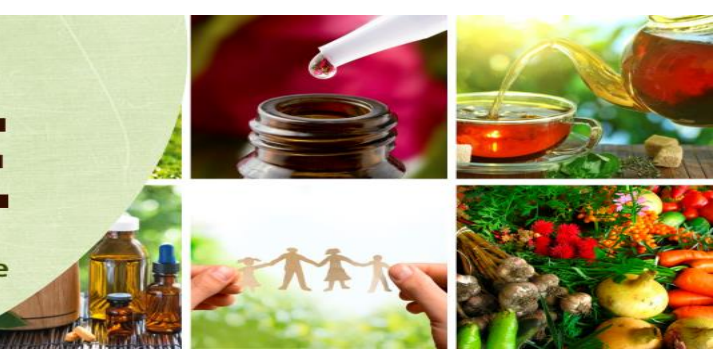

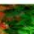

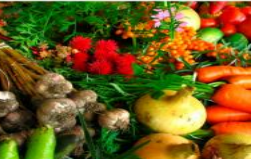

a vida, visando o trabalho com a harmonização de pensamentos e com emoções em desequilíbrio, tais como o medo, a insegurança e os pensamentos negativos.

Segundo Bach (1990), na natureza encontra-se recursos tais como ervas, plantas, árvores e flores, capazes de prevenir e de curar as enfermidades. Sendo assim, o sistema floral foi criado a partir do princípio de que o tratamento deve ser do indivíduo e não da enfermidade.

Conforme Bach (1990, p. 71):

Devido ao fato de a mente ser a parte mais delicada e sensível do corpo, nela aparecem mais claramente a gênese e o curso da enfermidade do que no resto do corpo, e é por isso que se utiliza a observação da mente como guia para conhecer que remédio ou que agrupamento de remédios é necessário.

Bach pôde verificar entre 1930 e 1934 a prática e eficácia dos medicamentos florais quando constatou que os remédios atuam sobre a desarmonia profunda do paciente, corrigindo o desequilíbrio emocional no campo energético (BACH, 1990).

Geng (2016) iniciou seu contato com as danças circulares sagradas no final dos anos de 1970 e, ao entrar em contato com o trabalho desenvolvido por Bach, por volta de 1995, foi incentivada por Mechthild Scheffer a trabalhar com as danças dos florais de Bach que, pelo movimento e o gesto simbólico, focam as qualidades positivas dos florais, promovendo possibilidades de autorregulação emocional.

Scheffer (1984) estudou o sistema dos 38 remédios do Dr. Bach, investigando a possibilidade de a personalidade poder regular estados de ânimo negativos, típicos da natureza humana, tais como: incerteza, ciúmes, desalento, entre outros. Os objetivos, tanto dos florais, quanto das danças circulares dos florais de Bach, são estimular autoconhecimento, o desenvolvimento harmonioso e, consequentemente, trazer maior equilíbrio diante de perturbações emocionais e, eventualmente, psicossomáticas.

Geng (2016) percebeu que as danças dos florais de Bach eram simples e que traziam a referência simbólica de proteção, retomando a sabedoria dos povos tradicionais da Látvia, onde a

Danças Circulares. Revista Revise, v.05, fluxo contínuo (2020): Dossiê experiências de integração ensino-serviço nas Práticas Integrativas e Complementares, p. 37-60. 


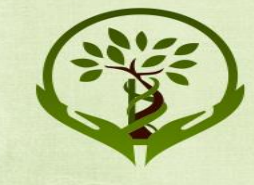

ISSN: $2179-6572$

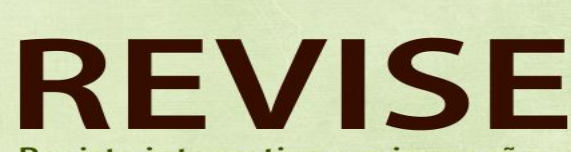

Revista integrativa em inovação tecnológica nas ciências da saúde
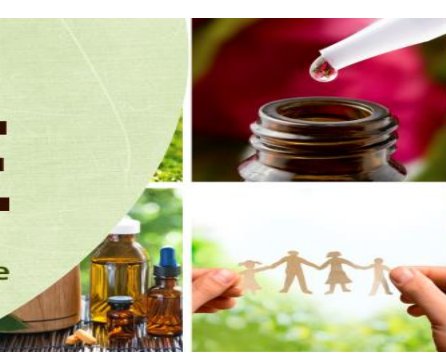

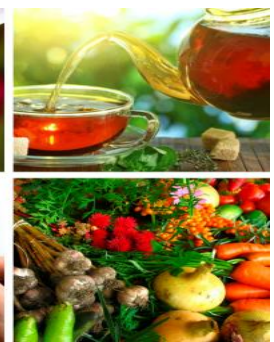

vida do povo é ligada a flores, árvores, estações e rios, tanto quanto à terra, à lua e, principalmente, ao sol.

De acordo com Barreto (2018, p. 2), “as danças dos florais de Bach trazem, além de movimentos simples, a recriação do que contém as gotas dos florais de Bach, abrindo espaço para a mudança e a evolução consciente, através dos passos que cada um precisa dar na vida".

Ainda de acordo com a autora, através das danças dos florais de Bach é possível integrar as qualidades positivas de cada flor, trabalhando seu potencial de cura, permitindo penetrar com simplicidade e profundidade no corpo e na alma. O movimento da roda, do círculo, ativa a energia de transformação das flores. Entrar no círculo para dançar reforça o vínculo com nós mesmos, com o outro e harmoniza o nosso ritmo com o pulsar da natureza.

As danças dos florais de Bach ajudam a remover bloqueios físicos e psicológicos criados por pensamentos e ações, restabelecendo assim o equilíbrio do ser e o contato com o Eu Superior. Quando a personalidade não está ligada à alma, há predominância de bloqueios de energia, distorções e desarmonias que causam as doenças (BARRETO, 2018, p. 10).

Essas danças, de acordo com aqueles que as vivenciam, abrem novas possibilidades para que cada pessoa possa se autorregular emocionalmente, seguir a orientação interior e encontrar ou reforçar seu potencial (missão, tarefa de vida) para aplicar seus talentos e capacidades na realização do propósito maior de sua existência, beneficiando a si mesmo e a coletividade.

\section{METODOLOGIA}

Delineamento: trata-se de estudo com abordagem predominantemente qualitativa (MINAYO, 2010), com alguma análise de dados quantitativos (GÜNTHER, 2006); pesquisaformação (PINEAU, 2006; FERREIRA, 2015); paradigma multirreferencial, envolvendo as histórias de vida (NÓVOA et al., 2013; JOSSO, 2010), destacando o lugar da intersubjetividade, com foco nas emoções.

Danças Circulares. Revista Revise, v.05, fluxo contínuo (2020): Dossiê experiências de integração ensino-serviço nas Práticas Integrativas e Complementares, p. 37-60. 


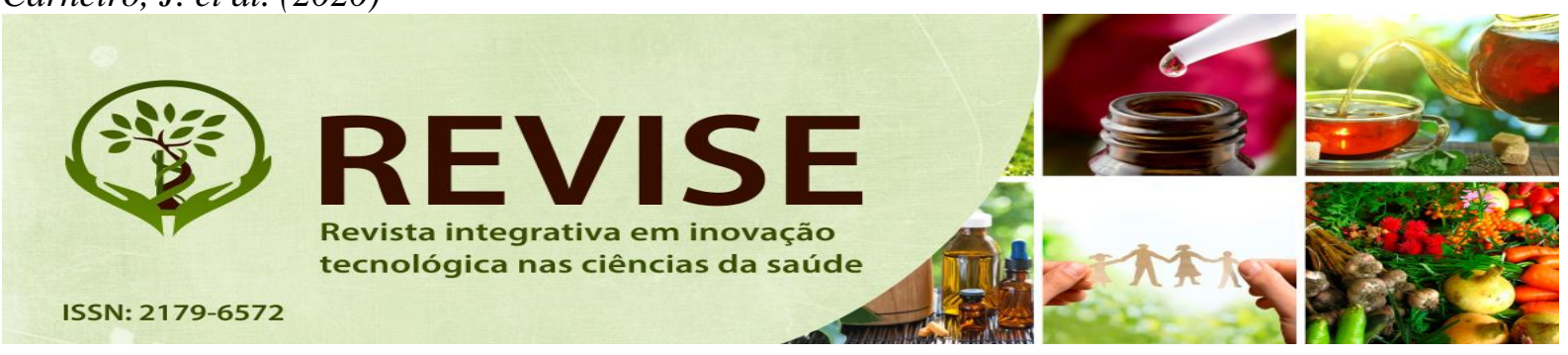

Contexto e seleção de participantes: no dia do encerramento da disciplina Projeto de Tese II, do doutorado em Educação da Faculdade de Educação da Universidade Federal da Bahia (FACEDUFBA), turma de ingresso no ano de 2017, momento de apresentação de pôsteres, referentes às pesquisas dos doutorandos, foram distribuídos 20 envelopes contendo um convite para a participação no corpus da pesquisa, uma cópia do pôster e os Termos de Consentimentos Livres e Esclarecidos (TCLE) em duas vias, explicitando todo o processo previsto na pesquisa. No convite, em formato de círculo, pedia-se ao colega para dar um retorno acerca da confirmação ou não da sua participação, via whatsapp, até uma determinada data, ou seja, um mês depois. Responderam ao convite, via whatsapp, 6 doutorandas, manifestando interesse em participar da pesquisa, 3 comunicaram a impossibilidade em participar por motivo de trabalho e/ou por estar afastado do local onde seria realizado o campo empírico e 11 pessoas não responderam ao convite.

Descrição das participantes: participaram do estudo seis doutorandas em Educação, graduações em Pedagogia, Educação Física, Letras, Jornalismo e Licenciatura em História, casadas, docentes, em sua maioria, com idades entre 32 e 63 anos, que ingressaram no curso de doutorado no primeiro semestre de 2017.

Vivências com 6 danças circulares dos Florais de Bach: as vivências ocorreram em 3 etapas, descritas a seguir: a) participantes dispostos em pé, em círculo: a pesquisadora demonstrou primeiramente a coreografia da dança e as participantes só observaram, ainda sem música (treinamento - 5 minutos); b) vivências das coreografias com as participantes: a pesquisadora dançou com as participantes, ainda sem música (treinamento - 5 minutos); c) vivências das danças circulares dos florais de Bach com as participantes: o grupo todo vivenciou as danças (5 minutos).

Instrumentos para produção de dados: os instrumentos para produção de dados foram os relatos verbais e as narrativas (auto)biográficas (PASSEGGI, 2010) acerca das emoções das doutorandas, a partir de seis danças circulares dos florais de Bach (OSTETTO; KOLBBERNARDES, 2015; GENG, 2016; BARRETO, 2018), dentro dos Ateliês Biográficos de Projeto (DELORYMOMBERGER, 2006), desenvolvidos com temas específicos referentes a: ordem interna (Crab Apple), intuição (Cerato), aprendizado (Chestnut Bud), responsabilidade (Elm), elevação (Rock Rose) e perdão (Willow), no período de três meses (abril - junho), em 2018.

Danças Circulares. Revista Revise, v.05, fluxo contínuo (2020): Dossiê experiências de integração ensino-serviço nas Práticas Integrativas e Complementares, p. 37-60. 


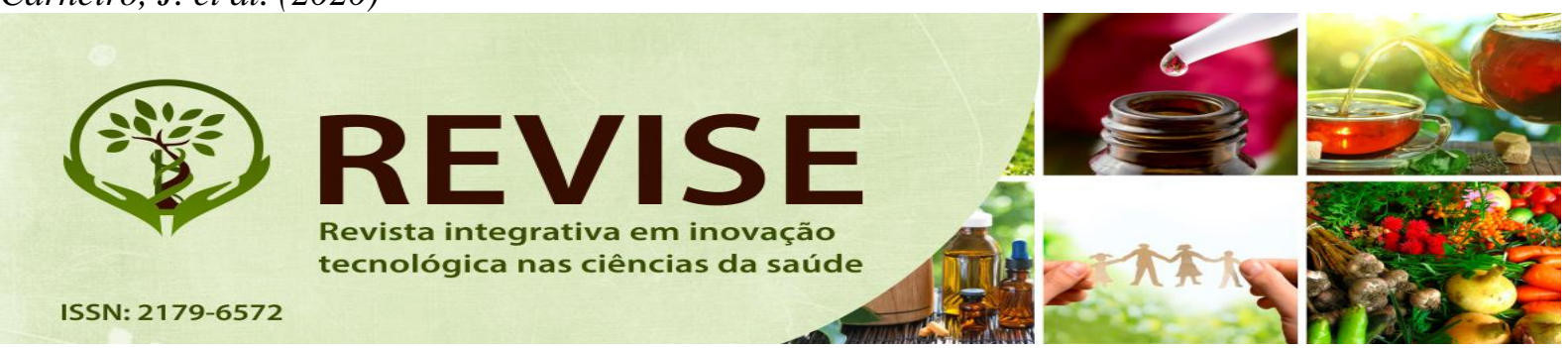

Organização e análise dos dados: os dados obtidos na pesquisa referentes às emoções foram registrados em gráficos (dados quantitativos) e mandalas (dados qualitativos). Adotou-se a técnica de análise de conteúdo (BARDIN, 2011) dos relatos verbais e das narrativas (auto)biográficas acerca das emoções vivenciadas durante um período do doutoramento em Educação. Dentro da técnica de análise de conteúdo, tomou-se a modalidade da análise temática para sondar o conteúdo qualitativo, com a busca das categorias comuns referentes às emoções das participantes, presentes tanto nos relatos verbais quanto nas narrativas (auto)biográficas, com foco nas emoções primárias/universais referentes à alegria, ao medo, à tristeza e à raiva.

Princípios éticos: as rodas de danças circulares foram conduzidas de acordo com as resoluções 466/12 (BRASIL, 2012) e 510/16 (BRASIL, 2016), que regem as pesquisas realizadas com seres humanos, obedecendo o rigor da privacidade e sigilo (Parecer do Comitê de Ética $\mathrm{N}^{\circ}$ 2.453.096). Foi informado que os anonimatos seriam preservados, sob forma de pseudônimos (nomes de algumas danças circulares dos florais de Bach), que foram escolhidos pelas participantes. Dessa forma, os Termos de Compromisso (TC) e de Consentimento Livre e Esclarecido (TCLE) foram assinados em duas vias.

\section{RESULTADOS E DISCUSSÃO}

Os resultados da pesquisa foram obtidos mediante a análise das categorias referentes às emoções vivenciadas pelas doutorandas em Educação, durante um período do doutoramento, expressas em relatos verbais e narrativas (auto)biográficas, a partir das danças circulares.

Foram registradas 15 emoções que mais se repetiram, tanto nos relatos verbais, quanto nas narrativas (auto)biográficas das participantes, tendo destaque para: 1 ) alegria $=18 \% ; 2$ ) confiança $=$ $17 \%$; 3) medo $=11 \%$; 4) ânimo $=10 \%$ e 5) resiliência/superação/leveza $=7 \%$. Tais resultados apontam a presença significativa da alegria, confiança, ânimo, leveza e resiliência/superação, emoções positivas/conjuntivas e integrativas, associadas a condutas de aproximação, participação, cooperação, união, contato, satisfação e bem-estar entre as participantes. Por outro lado, a presença

Danças Circulares. Revista Revise, v.05, fluxo contínuo (2020): Dossiê experiências de integração ensino-serviço nas Práticas Integrativas e Complementares, p. 37-60. 


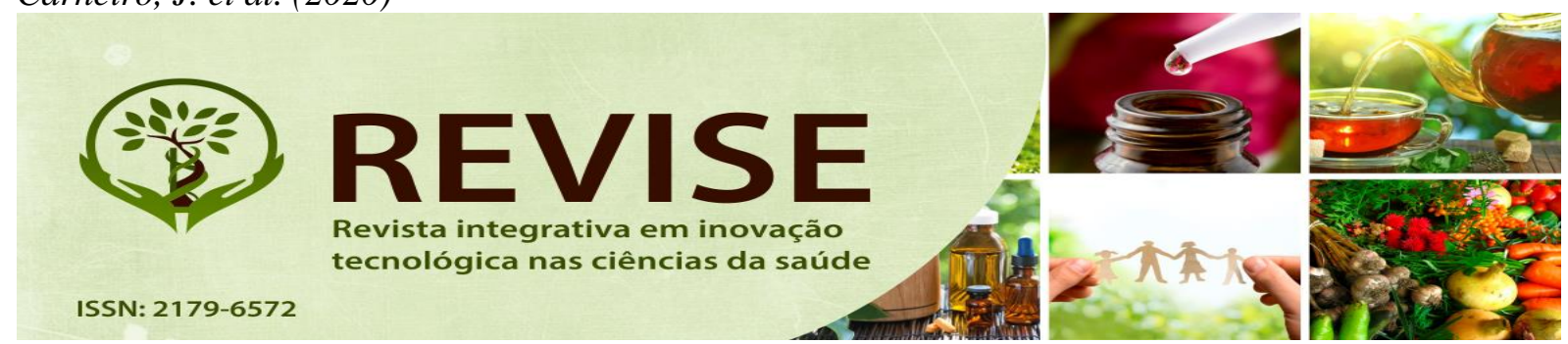

da emoção do medo é demasiadamente forte, mostrando que tal emoção necessita ser trabalhada pelas participantes durante o doutoramento, no sentido de buscar superação e transformação.

Os relatos verbais a partir das escutas, feitos durante os momentos de acolhimento, envolvendo as harmonizações inicial, final e as vivências com as danças circulares dos florais de Bach (Rock Rose - tranquilidade; Willow - receptividade; Crab Apple - amor; Cerato - acolhimento), evidenciaram o contato com emoções positivas, conjuntivas e integrativas (MATURANA, 1998; ADLER, 1957; ACCIOLY; ATHAYDE, 1996), associadas a condutas amorosas, de aproximação, confiança e vínculo entre as participantes da pesquisa, bem ilustrada na citação do autor. "O amor é a emoção... em que se dá a operacionalidade da aceitação do outro como legítimo outro na convivência" (MATURANA, 1998, p. 23).

As narrativas (auto)biográficas das participantes Chestnut Bud, Elm, Rock Rose e Willow evidenciaram algumas emoções consideradas disjuntivas (ADLER, 1957), envolvendo medo, preocupação, insegurança ou ambivalências diante do ingresso no doutorado. Tais narrativas das participantes se assemelham, de alguma forma, a algumas narrativas extraídas do jornal Folha de São Paulo (MORAES, 2017), que relatam o estado mental dos alunos de mestrado e doutorado em sofrimento psíquico, apontando intensos sintomas, a relação difícil e persecutória com o (a) orientador (a), a rejeição à dissertação e/ou tese, o sentimento de humilhação social, a escassez dos recursos materiais e financeiros durante a pós-graduação, citados na segunda seção deste artigo, "Emoções na Pós-Graduação".

Araújo (2018) adverte sobre a necessidade de cuidado com os processos de formação emocional, sinalizando sobre a importância da abertura da alma para a intensidade dos desafios da vida; aponta também a respeito do cuidado com a autodisciplina e o autoconhecimento, que precisa ser permanente. Os momentos formativos são, portanto, de acordo com o autor, marcados pela complementaridade entre momentos de prazer e de dor, de alegria e tristeza, de sim e de não, enquanto expressões dos fluxos de emoções e sentimentos.

Ainda em relação às categorias referentes às emoções vivenciadas pelas doutorandas em Educação, expressas tanto em relatos verbais quanto nas narrativas (auto)biográficas, a partir das danças circulares dos florais de Bach durante a pesquisa, verificou-se no grupo pesquisado os

Danças Circulares. Revista Revise, v.05, fluxo contínuo (2020): Dossiê experiências de integração ensino-serviço nas Práticas Integrativas e Complementares, p. 37-60. 


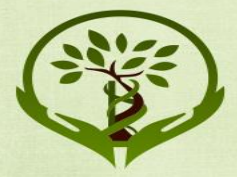

ISSN: 2179-6572

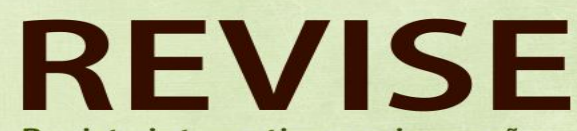

Revista integrativa em inovação tecnológica nas ciências da saúde

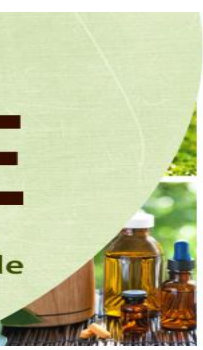

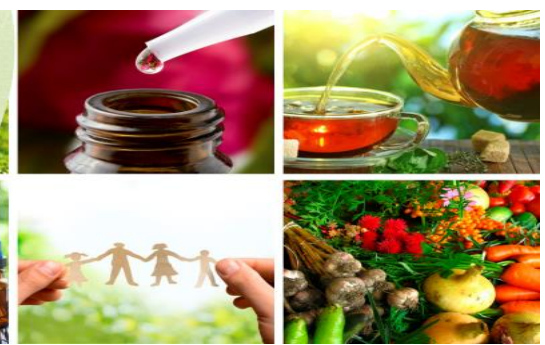

seguintes percentuais para as quatro emoções universais e seus equivalentes semânticos (DARWIN, 2009; EKMAN, 2011; ADLER, 1957; ACCIOLY; ATHAYDE, 1996): alegria (82\%); medo (14\%); tristeza $(3 \%)$ e raiva $(1 \%)$. Torna-se importante mencionar os equivalentes semânticos aqui considerados. Para a alegria considerou-se: amor, ânimo, bem-estar, confiança, equilíbrio, força, gratidão, leveza, libertação, paz, resiliência/superação e tranquilidade. Para o medo, foi considerada a fragilidade como um equivalente semântico. No caso da raiva, considerou-se a tensão e para a tristeza, elegeu-se a dimensão da quietude.

Depreendem-se alguns entendimentos acerca do predomínio e do destaque para a emoção da alegria e seus equivalentes semânticos. Observou-se que, na maioria dos relatos verbais, as participantes fizeram menção sobre a importância do acolhimento, do cuidado, do contato, da presença, do vínculo, da "boa energia" que emanava das rodas de danças circulares dos florais de Bach, do significado simbólico do círculo, que se constituiu em um espaço democrático, sem hierarquias, sem competição, que possibilitou a cooperação, a união e a alegria entre as participantes.

\section{CONCLUSÃO}

O objetivo geral do presente estudo foi compreender como são vivenciadas as emoções de doutorandas em Educação, durante um período do doutoramento, expressas em relatos verbais e narrativas (auto)biográficas a partir das danças circulares. A partir deste estudo, foi possível identificar que as doutorandas em Educação, na FACED-UFBA, percebem a necessidade de tomar consciência, de cuidar das suas emoções, de refletir sobre a natureza delas (positivas/conjuntivas, negativas/disjuntivas ou ambivalentes) e de trabalhar o autoconhecimento, demonstrando, portanto, uma atenção e cuidado com a sua Saúde Mental, sendo que tal percepção é variável entre as participantes, aparecendo de modo não uniforme no grupo investigado.

Desse modo, torna-se importante sugerir neste trabalho, a necessidade de se constituir na instituição investigada, como foi destacado na segunda seção do presente artigo e conforme ocorrido em outra instituição educativa universitária (UFMG), um serviço de atenção ao estudante na PósGraduação, na área de Saúde Mental, serviços esses ainda escassos ou quase inexistentes. Vale 

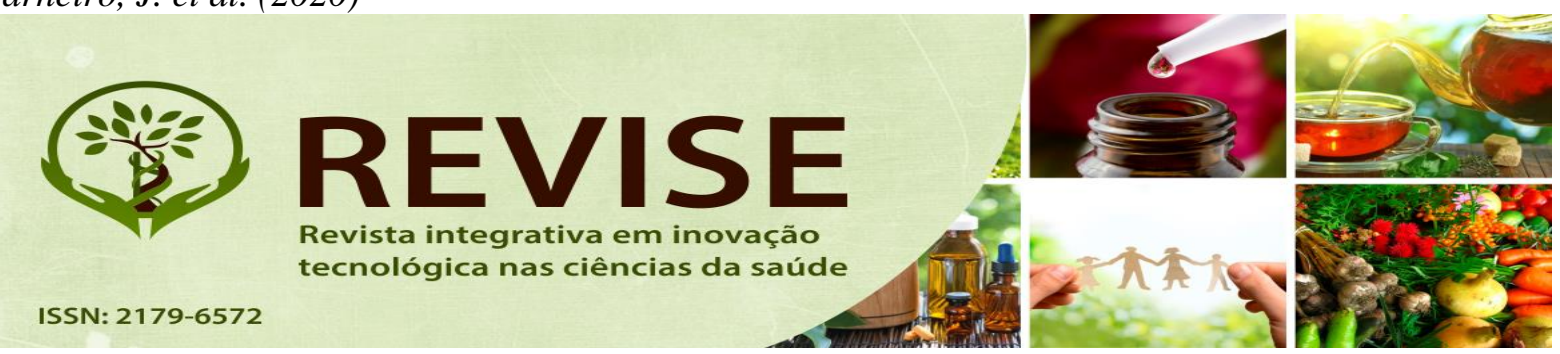

ressaltar, ainda, que, conforme apontado na literatura pesquisada, as universidades brasileiras não sabem ou não têm conhecimento acerca do que se passa com a Saúde Mental dos seus estudantes de Pós-Graduação, devendo, portanto, ser alvo de futuras pesquisas.

No caso da UFBA, temos o Serviço Médico Universitário Rubens Brasil (SMURB), cuja missão é desenvolver ações integradas de atenção à saúde dos trabalhadores e estudantes da UFBA, através de ações de prevenção, assistência, vigilância, perícia, reabilitação e inclusão (SAMPAIO, 2011). Funciona com uma equipe multiprofissional e, no tocante à Saúde Mental, oferece as Práticas Integrativas e Complementares (PICS), com o objetivo de prestar serviços assistenciais visando ao equilíbrio emocional dos usuários. No entanto, observamos uma demanda excessiva no referido serviço, o que desencadeia a geração de listas de esperas para atendimentos na área de Saúde Mental.

Este estudo aponta, portanto, a necessidade da prática do saber sensível na Pós-Graduação em Educação, com o desenvolvimento de trabalhos formativos que possam estimular e promover a expressão de emoções positivas/conjuntivas, tais como: alegria, confiança, ânimo, resiliência/superação, leveza, entre outras, as quais foram referidas pelas participantes, durante o processo de formação.

A tese defendida neste artigo é a de que as danças circulares são Práticas Integrativas e Complementares que promovem emoções positivas/conjuntivas e possibilitam um diagnóstico de outras emoções, consideradas negativas/disjuntivas, capazes de provocar sofrimento psíquico, afetando a Saúde Mental de pós-graduandos e, consequentemente, sua vida acadêmica, podendo trazer repercussões negativas para a universidade.

Compreender as emoções de doutorandas em Educação no processo formativo, em uma perspectiva sensível, na FACED-UFBA, pode contribuir para a criação de condições de formação nessa unidade, como também pode dar visibilidade a outros programas de pós-graduação, no sentido de buscarem ampliar possibilidades de inserir propostas de auto formação, visando ao cuidado com as emoções e à autorregulação emocional de doutorandos durante o período do curso de doutorado.

Identificamos, ainda, a partir dos resultados da pesquisa, outras possibilidades de investigação: 1) Como compreender as emoções de doutorandos em Educação, em estudos longitudinais, na FACED-UFBA, uma vez que o universo da pesquisa desenvolvida foi integração ensino-serviço nas Práticas Integrativas e Complementares, p. 37-60. 


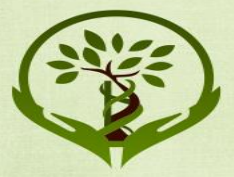

ISSN: 2179-6572

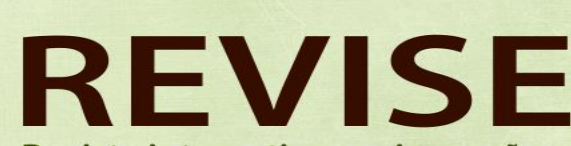

Revista integrativa em inovação tecnológica nas ciências da saúde
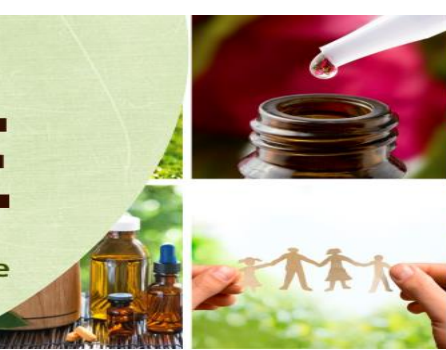

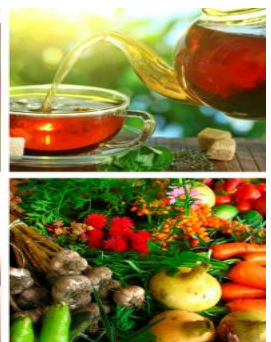

eminentemente feminino e apenas por um determinado período?; 2) Como compreender as emoções de doutorandas em Educação, a partir de outras Práticas Integrativas e Complementares, tais como meditação e relaxamento?; 3) Como as emoções encontradas na pesquisa realizada com as doutorandas em Educação podem servir para a reflexão sobre o processo de formação em outros cursos de Pós-Graduação na instituição pesquisada e em outras instituições universitárias?

\section{REFERÊNCIAS}

ACCIOLY, J.; ATHAYDE, A. Educação emocional: o caminho para a competência emocional. Cidade: Gráfica Santa Helena, 1996.

ADLER, A. A ciência da natureza humana. 4. ed. São Paulo: Companhia Editora Nacional, 1957.

ARAÚJO, M. A. L. Feixes de arco-íris: uma compreensão ontológico-policrômica da sensibilidade e sua fruição no fenômeno do educar. Tese (Doutorado em Educação) - Faculdade de Educação da Universidade Federal da Bahia (FACED - UFBA). Programa de Pós-Graduação em Educação Salvador, 2006.

ARAÚJO, M. A. L. O cuidado com as emoções. Jornal Fuxico, Feira de Santana (UEFS), BA, v. 16, n. 42, set./dez. 2018, (p. 05-07).

BACH, E. Os remédios florais do Dr. Bach. 19. ed. São Paulo: Editora Pensamento, 1990.

BARBIER, R. A pesquisa-ação. Brasília: Liber Livro, 2002.

BARDIN, L. Análise de conteúdo. Ed. rev. e ampl. São Paulo: Edições 70, 2011.

BARRETO, S. (coord.). Dançando os florais de Bach: com as danças circulares sagradas. Salvador, 2018. Módulos 1 - 5. Formação para facilitadores. Não publicado.

BARRETO, S. (coord.). Danças circulares: desenvolvendo pessoas e organizações. Salvador, 2014. Módulos 1 - 6. Formação para facilitadores. Não publicado.

BÉRGAMO, M.; MORAES, F. T. Universidades não têm diagnóstico da saúde mental de seus alunos de pós. Folha de São Paulo, São Paulo, 20 dez. 2017. Seção Ciência. Disponível em: https://www1.folha.uol.com.br/ciencia/2017/12/1944690-universidades-nao-tem-diagnostico-dasaude-mental-dos-alunos-de-pos.shtml. Acesso em: 19/01/2018.

Danças Circulares. Revista Revise, v.05, fluxo contínuo (2020): Dossiê experiências de integração ensino-serviço nas Práticas Integrativas e Complementares, p. 37-60. 

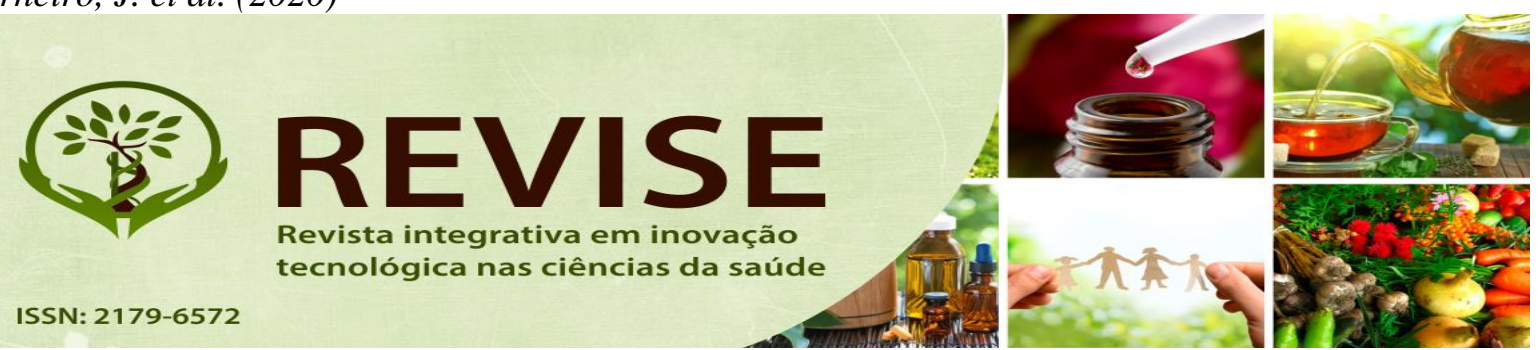

BESCHE-RICHARD, C.; BUNGENER, C. Psicopatologias, emoções e neurociências. Lisboa: Climepsi, 2008.

BRASIL. CONSELHO NACIONAL DE SAÚDE. Resolução n. 466, de 12 de dezembro de 2012. Aprova diretrizes e normas de pesquisas envolvendo seres humanos. Brasília, 2012. Disponível em: http://conselho.saude.gov.br/resolucoes/2012/reso466.pdf. Acesso em: 28/03/2018.

BRASIL. CONSELHO NACIONAL DE SAÚDE. Resolução n. 510, de 7 de abril de 2016. Dispõe sobre as normas aplicáveis a pesquisas em Ciências Humanas e Sociais. Brasília, 2016. Disponível em: http://conselho.saude.gov.br/resolucoes/2016/reso510.pdf. Acesso em: 28/03/2018.

BRASIL. MINISTÉRIO DA SAÚDE. Portaria nº 849, de 27 de março de 2017. Expande a Política Nacional de Práticas Integrativas e Complementares (PNPIC) no Sistema Único de Saúde. Brasília, 2017. Disponível em:

http://189.28.128.100/dab/docs/portaldab/documentos/prt_849_27_3_2017.pdf. Acesso em: 28/03/2018.

CARVALHO, C. S. Introdução às danças circulares sagradas. In: RAMOS, R. C. L. (org.). Danças circulares sagradas: uma proposta de educação e cura. 2. ed. - reimpressão. São Paulo: Triom, 2017, (p. 07-10).

DALGALARRONDO, P. Psicopatologia e semiologia dos transtornos mentais. Porto Alegre: Artmed, 2000.

DAMÁSIO, A. R. Em busca de Espinosa: prazer e dor na ciência dos sentimentos. São Paulo: Companhia das Letras, 2004.

DAMÁSIO, A. R. O erro de descartes: emoção, razão e cérebro humano. São Paulo: Companhia das Letras, 1996.

DARWIN, C. A expressão das emoções no homem e nos animais. São Paulo: Companhia das Letras, 2009.

DELORY-MOMBERGER, C. Formação e socialização: os ateliês biográficos de projeto. Educação e Pesquisa, v. 32, n. 2, maio/ago. 2006, (p. 359-371). Disponível em: https://www.scielo.br/pdf/ep/v32n2/a11v32n2.pdf. Acesso em: 09/06/2020.

DESCARTES, R. As paixões da alma. São Paulo: Lafonte, 2012.

Danças Circulares. Revista Revise, v.05, fluxo contínuo (2020): Dossiê experiências de integração ensino-serviço nas Práticas Integrativas e Complementares, p. 37-60. 


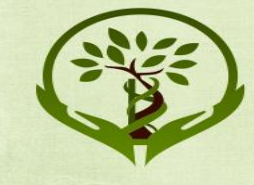

ISSN: 2179-6572

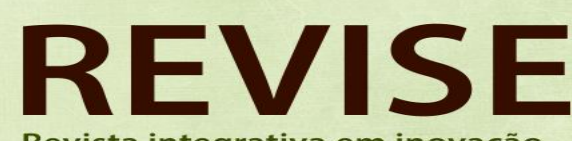

Revista integrativa em inovação tecnológica nas ciências da saúde

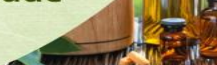

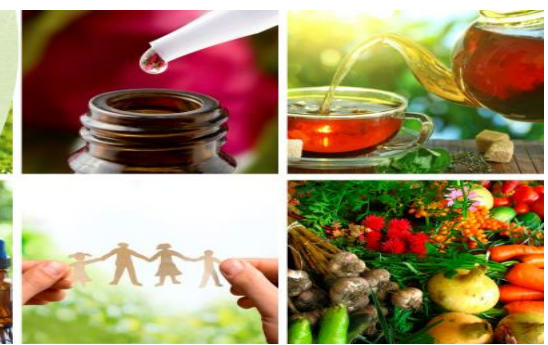

DUARTE-JÚNIOR, J. F. Entrevista João Francisco Duarte Júnior. Revista Contrapontos Eletrônica, v. 12, n. 3, set./dez. 2012, (p. 362-367). Disponível em: https://www6.univali.br/seer/index.php/rc/article/viewFile/4039/2387. Acesso em: 09/06/2020.

EKMAN, P. A linguagem das emoções: revolucione sua comunicação e seus relacionamentos reconhecendo todas as expressões das pessoas ao redor. São Paulo: Lua de Papel, 2011.

FERREIRA, L. G. Os ateliês biográficos de projeto e os processos formativos de professores: diálogos, (auto)biografia e ludicidade. Aprender: Caderno de Filosofia e Psicologia da Educação, Vitória da Conquista, v. 19, n. 15, jul./dez. 2015, (p. 99-110). Disponível em: http://periodicos2.uesb.br/index.php/aprender/article/download/2458/2027/. Acesso em: 09/06/2020.

GENG, A. As danças dos florais de Bach. São Paulo: Triom, 2016.

GÜNTHER, H. Pesquisa Qualitativa Versus Pesquisa Quantitativa: Esta É a Questão? Psicologia: Teoria e Pesquisa, v. 22, n. 2, maio/ago. 2006, (p. 201-210). Disponível em: https://www.scielo.br/pdf/ptp/v22n2/a10v22n2.pdf. Acesso em: 09/06/2020.

HARRIS, P. L. Criança e emoção: o desenvolvimento da compreensão psicológica. São Paulo: Martins Fontes, 1996.

JOSSO, M. C. Experiências de vida e formação. 2. ed. rev. e ampl. São Paulo: Paulus, 2010.

JUNTA, C. Estresse e depressão na pós-graduação: uma realidade que a academia insiste em não ver. Associação Nacional de Pós-Graduandos, abr. 2017. Disponível em:

http://www.anpg.org.br/03/04/2017/estresse-e-depressao-na-pos-graduacao-uma-realidade-que-aacademia-insiste-em-nao-ver/. Acesso em: 09/06/2020.

LESSA, J. M. A clínica como exercício ético dos encontros afetivos. São Luís: EDUFMA, 2014.

LIPP, M. E. N.; GUEVARA, A. J. H. Validação empírica do Inventário de Sintomas de Stress (ISS). Estudos de Psicologia, v. 11, n. 3, 1994, (p. 43-49). Disponível em: https://www.researchgate.net/publication/284507885_Validacao_empirica_do_inventario_de_sinto mas_de_stress. Acesso em: 09/06/2020.

LOWEN, A. Alegria. São Paulo: Summus, 1997.

LOWEN, A. O conceito de energia. In: LOWEN, A. Bioenergética. São Paulo: Summus, 1982, (p. 40-71).

Danças Circulares. Revista Revise, v.05, fluxo contínuo (2020): Dossiê experiências de integração ensino-serviço nas Práticas Integrativas e Complementares, p. 37-60. 


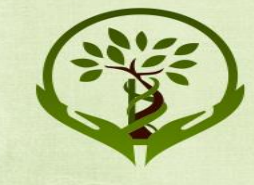

ISSN: $2179-6572$

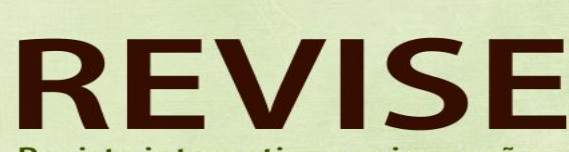

Revista integrativa em inovação tecnológica nas ciências da saúde

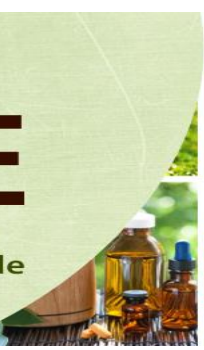

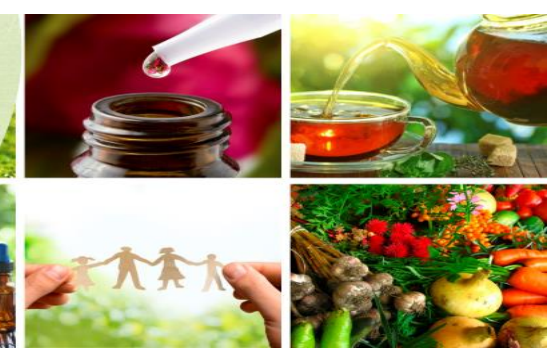

LOWEN, A. O ego e o corpo. In: LOWEN, A. O corpo traído. São Paulo: Summus, 1979, (p. 248263).

MACEDO, R. S. Compreender/mediar a formação: o fundante da educação. Brasília: Liber Livro Editora, 2010.

MAFFESOLI, M. Elogio da razão sensível. Petrópolis, RJ: Vozes, 1998.

MALAGRIS, L. E. N., et. al. Níveis de estresse e características sociobiográficas de alunos de pósgraduação. Psicologia em Revista, v. 15, n. 1, abr. 2009, (p. 184-203). Disponível em: http://periodicos.pucminas.br/index.php/psicologiaemrevista/article/view/P.16789563.2009v15n2p184/876. Acesso em: 09/06/2020.

MATURANA R., H. Emoções e linguagem na educação e na política. Belo Horizonte: Ed. UFMG, 1998.

MINAYO, M. C. de S. O desafio do conhecimento. 10. ed. São Paulo: Hucitec, 2010.

MIRA Y LÓPEZ, E. Quatros gigantes da alma. 15. ed. Rio de Janeiro: José Olympio, 1992.

MORAES, F. T. Estudantes de mestrado e doutorado relatam suas dores na pós-graduação. Folha de São Paulo, São Paulo, dez. 2017. Seção Ciência. Disponível em:

https://www1.folha.uol.com.br/ciencia/2017/12/1943862-estudantes-de-mestrado-e-doutoradorelatam-suas-dores-na-pos-graduacao.shtml?origin=folha. Acesso em: 19/01/2018.

NÓVOA, A., et. al. Vida de professores. Porto, PT: Porto Editora, 2013.

OSTETTO, L. E.; KOLB-BERNARDES, R. Modos de falar de si: a dimensão estética nas narrativas autobiográficas. Pró-Posições, v. 26, n. 1, jan./abr. 2015, (p. 161-178). Disponível em: https://www.scielo.br/pdf/pp/v26n1/0103-7307-pp-26-01-0161.pdf. Acesso em: 09/06/2020.

PASSEGGI, M. da C. Narrar é humano! Autobiografar é um processo civilizatório. In: PASSEGGI, M. da C.; SILVA, V. B. (org.). Invenções de vidas, compreensão de itinerários e alternativas de formação. São Paulo: Cultura Acadêmica, 2010, (p. 103-130).

PINEAU, G. As histórias de vida em formação: gênese de uma corrente de pesquisa-ação-formação existencial. Educação e Pesquisa, v. 32, n. 2, maio/ago. 2006, (p. 329-343). Disponível em: http://www.revistas.usp.br/ep/article/view/28013/29803. Acesso em: 09/06/2020.

Danças Circulares. Revista Revise, v.05, fluxo contínuo (2020): Dossiê experiências de integração ensino-serviço nas Práticas Integrativas e Complementares, p. 37-60. 


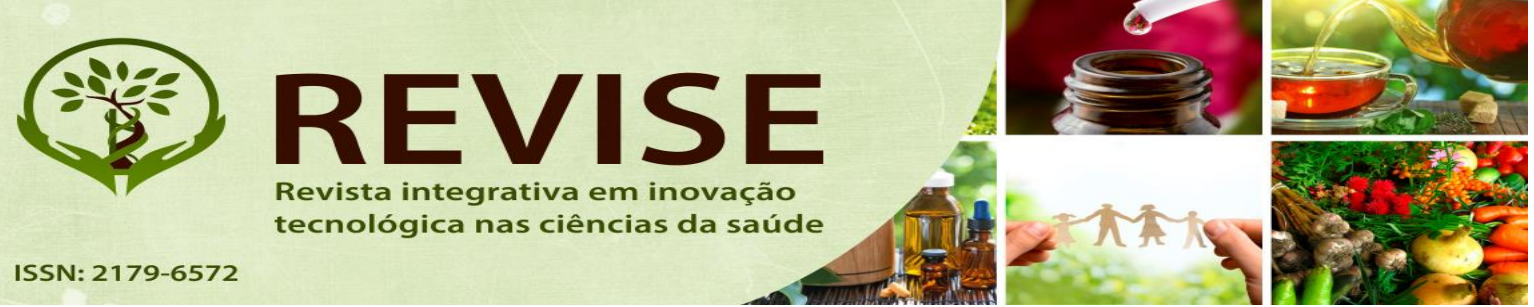

SAMPAIO, D. B. P. (org.). Projeto de criação do Ambulatório de Medicina Tradicional de Práticas Integrativas/Complementares. Universidade Federal da Bahia. Salvador, 2011. Não publicado.

SCHEFFER, M. Experiências com a terapia floral do dr. Bach: com um questionário para diagnóstico. São Paulo: Pensamento, 1984.

WOSIEN, B. Dança: um caminho para a totalidade. São Paulo: Triom, 2000.

Danças Circulares. Revista Revise, v.05, fluxo contínuo (2020): Dossiê experiências de integração ensino-serviço nas Práticas Integrativas e Complementares, p. 37-60. 